\title{
KELAYAKAN REKAYASA TAMBAK SILVOFISHERY DI KECAMATAN BLANAKAN KABUPATEN SUBANG PROVINSI JAWA BARAT
}

\author{
Tarunamulia\#, Akhmad Mustafa, Hasnawi, dan Kamariah \\ Balai Penelitian dan Pengembangan Budidaya Air Payau \\ (Naskah diterima: 10 Juli 2015; Revisi final: 30 Oktober 2015; Disetujui publikasi: 9 November 2015)
}

\begin{abstract}
ABSTRAK
Di Indonesia, silvofishery diharapkan dapat menjadi salah satu alternatif terbaik untuk mencapai pengelolaan ekosistem mangrove dan tambak ekstensif secara optimal dan berkelanjutan. Penelitian ini bertujuan untuk mengevaluasi status kelayakan rekayasa tambak silvofishery di Desa Jayamukti Kecamatan Blanakan Kabupaten Subang Provinsi Jawa Barat. Evaluasi dilakukan dengan menerapkan metode survai tingkat detail yang berbasis sistem informasi geografis (SIG) dan memanfaatkan citra satelit worldview-2. Survai lapang meliputi pengambilan contoh tanah, pengukuran elevasi lahan tambak, pengukuran pasang surut, dan pengukuran kualitas air secara insitu. Hasil kajian ini menunjukkan bahwa kondisi rekayasa tambak eksisting dapat berpengaruh langsung maupun tidak langsung pada produktivitas dan keberlanjutan tambak silvofishery di lokasi studi. Ketidaksesuaian lebar dan kedalaman saluran dengan kondisi tunggang pasut lokal $(<1 \mathrm{~m})$ menyebabkan tidak efektifnya fungsi saluran dalam menyediakan kuantitas dan kualitas air yang optimal untuk kegiatan budidaya. Selanjutnya penelitian ini juga menemukan ketinggian pematang primer dan sekunder eksisting umumnya lebih rendah dibandingkan ketinggian pematang ideal dengan selisih rata-rata masing-masing $-0,68 \mathrm{~m}$ hingga $-0,56 \mathrm{~m}$. Nilai salinitas air dengan kisaran 7-65 ppt juga merupakan faktor pembatas utama produktivitas lahan. Nilai salinitas air tambak yang tinggi berkaitan erat dengan variasi spasial elevasi dasar tambak dan penurunan efektivitas fungsi saluran tambak akibat sedimentasi. Jika faktor pembatas lingkungan dan ketidaksesuaian rekayasa tambak tersebut tidak ditangani dengan baik tentunya akan mengancam keberlanjutan kegiatan budidaya berbasis silvofishery di lokasi penelitian.
\end{abstract}

KATA KUNCI: silvofishery, rekayasa tambak, kualitas lingkungan, SIG, Kabupaten Subang

ABSTRACT: The engineering suitability of silvofishery-based brackishwater aquaculture in Blanakan District Subang Regency West Java Province. By: Tarunamulia, Akhmad Mustafa, Hasnawi, and Kamariah

\begin{abstract}
In Indonesia, silvofishery has been expected to be one of alternative approaches to achieve the optimum and sustainable management of extensive brackishwater pond and mangrove. The objective of this study was to evaluate pond engineering suitability of silvofishery-based brackishwater ponds in Jayamukti Village Blanakan Sub-District Subang Regency West Java Province. The land and pond engineering suitability evaluations were conducted following detailed survey method, employing high-resolution satellite imagery of worldview-2, and geographical information system (GIS). The field survey involved soil sampling, in situ water quality measurement, measurement of land elevation, and tide observation. The results indicated that the current status of pond engineering as well as their direct and indirect effects on the change in the quality of environmental variables could potentially limit the productivity and sustainability of silvofishery in the study area. Inadequate supply of required volume and quality of seawater to support the silvofishery was primarily due to inappropriate dimension of canal width and depth with respect to local tidal range $(<1 \mathrm{~m})$. Additionally, this study also found the elevation of most primary and secondary dykes somewhat lower than calculated ideal dyke elevations, with the average difference value of $-0.68 \mathrm{~m}$ and $-0.56 \mathrm{~m}$ respectively. The salinity of pond water ranging from 7 to 65 ppt was also considered to be a significant limiting factor to pond productivity. This wide range in salinity values was relating to high spatial variation of pond bed elevation and ineffectual canal due to high sedimentation rate reducing water exchange. The increased productivity and the sustainability of silvofishery in the
\end{abstract}

\# Korespondensi: Balai Penelitian dan Pengembangan

Budidaya Air Payau. Jl. Makmur Dg. Sitakka No. 129, Maros

90512, Sulawesi Selatan, Indonesia. Tel.: + (0411) 371544

E-mail: tarunamulia@yahoo.com 
region cannot be achieved without significant improvement in pond engineering and a better understanding as well as management of existing environmental limiting factors.

KEYWORDS: $\quad$ silvofishery, pond engineering, environmental quality, GIS, Subang Regency

\section{PENDAHULUAN}

Potensi tambak air payau di Indonesia berdasarkan data statistik perikanan budidaya tahun 2009 dan 2010, tercatat seluas 2.963 .717 ha, akan tetapi yang dimanfaatkan baru seluas 682.857 ha (KKP, 2011). Untuk meningkatkan produksi dan mengelola petensi lahan seluas itu, Kementerian Kelautan dan Perikanan (KKP) telah melakukan program minapolitan dan industrialisasi perikanan budidaya tambak yang di dalamnya meliputi program revitalisasi tambak. Sehubungan dengan program revitalisasi tambak ini, KKP pada tahun 2014 menargetkan 135.000 ha tambak dengan target produksi sebesar 214.120 ton atau senilai 13,7 triliun (Antara-Kalsel, 2012).

Kabupaten Subang merupakan salah satu kabupaten dari enam kabupaten di wilayah pantura (pantai Utara) Pulau Jawa, yang menjadi target program revitalisasi tambak tahap pertama KKP. Dari total 1.000 ha lahan yang diperuntukkan untuk tahap awal revitalisasi tambak, di pantura Jawa Barat, sekitar 45\% atau seluas 360 ha berlokasi di Kabupaten Subang. Komoditas utama yang menjadi andalan adalah udang windu (Penaeus monodon) dan bandeng (Chanos chanos). Pemilihan lokasi revitalisasi tambak didasari oleh potensi utama wilayah tersebut untuk menggenjot kapasitas produksi udang nasional sekaligus sebagai entry point dalam percepatan pembangunan industrialisasi perikanan budidaya di Indonesia (Antara, 2012). Program revitalisasi di pantai Utara Jawa antara lain difokuskan pada perbaikan infrastruktur melalui efisiensi dan efektivitas rekayasa tambak dan perbaikan cara pengelolaan tambak berdasarkan karakteristik lingkungan.

Penurunan kualitas lahan akibat pengelolaan yang tidak ramah lingkungan telah terjadi hampir di seluruh kawasan pantai Utara Jawa Barat termasuk kawasan pantai Kabupaten Subang (Sutirda, 2000). Kondisi ini mendorong masyarakat pantai khususnya pembudidaya untuk mencari alternatif pendapatan dengan mengembangkan wilayah tambak ke areal mangrove. Sejak 1970-an sejumlah lahan mangrove yang dikelola oleh perum perhutani secara ilegal dikonversi menjadi lahan tambak (Primavera, 2000). Untuk mengantisipasi hal tersebut pada tahun 1976 perum perhutani menerapkan sistem perhutanan sosial yang juga dikenal dengan istilah wanamina atau silvofishery (Primavera, 2000; Wibowo \& Handayani, 2006). Secara sederhana sistem silvofishery ini dapat dijelaskan sebagai suatu upaya pengelolaan terpadu antara mangrove dan tambak melalui penanaman pohon pada petakan tambak, baik pada pelataran maupun pinggir pematang (Sambu, 2013; Sutirda, 2000; Triyanto et al., 2012). Hingga tahun 2000 luas lahan tambak silvofishery di Kabupten Subang dilaporkan telah mencapai sekitar 5.300 ha dengan kisaran produksi udang budidaya $(200-300 \mathrm{~kg} / \mathrm{ha} /$ tahun); bandeng budidaya (500-700 kg/ha/tahun) dan udang/ikan liar (100-400 kg/ha/tahun) (Primavera, 2000; Sutirda, 2000). Produksi udang tersebut hampir sama dengan hasil yang didapatkan pada teknologi mixed shrimp-mangrove forestry di Provinsi Tam Giang, Vietnam dengan produksi rata-rata $286( \pm 106) \mathrm{kg} / \mathrm{ha} /$ tahun (Johnston et al., 2000). Produksi maksimal didapatkan umumnya pada petakan dengan rasio mangrove dan tambak 80\% : 20\% (Takasima dalam Primavera, 2000; Wibowo \& Handayani, 2006).

Pelaksanaan silvofishery di Indonesia terkendala oleh berbagai faktor antara lain kurang tersedianya daya dukung teknis seperti informasi karakteristik bio-fisik lahan dan aspek rekayasa tambak sehubungan dengan syarat teknis organisme tambak yang dibudidayakan dan termasuk syarat hidup spesies mangrove yang digunakan (Wibowo \& Handayani, 2006). Menurut Sukardjo (1989) dan Primavera (2000), aspek rekayasa tambak yang harus dikaji lebih lanjut antara lain rasio air (kolam) dan mangrove, volume dan luas wilayah optimum petakan, lebar pintu air, bilasan pasut (tidal flushing), dan elevasi pelataran mangrove. Penelitian ini bertujuan untuk mengevaluasi kelayakan rekayasa tambak, serta hubungannya dengan keberlanjutan dan tingkat produktivitas tambak berbasis silvofishery di Kabupaten Subang, Jawa Barat.

\section{BAHAN DAN METODE}

\section{Lokasi dan Waktu Penelitian}

Penelitian dilaksanakan di kawasan pertambakan Desa Jayamukti Kecamatan Blanakan Kabupaten Subang, Jawa Barat (Gambar1). Lokasi pertambakan ini merupakan bagian kawasan minapolitan di Kecamatan Blanakan. Analisis kualitas tanah dan air sebagian besar dilakukan di Laboratorium Tanah Balai Penelitian dan Pengembagan Budidaya Air Payau (BPPBAP) di Maros, Sulawesi Selatan. Kegiatan lapang dilakukan dalam dua tahap meliputi survai pendahuluan yang dilaksanakan pada bulan Januari dan survai lapang tahap kedua pada bulan Mei 2014, sedangkan kegiatan 


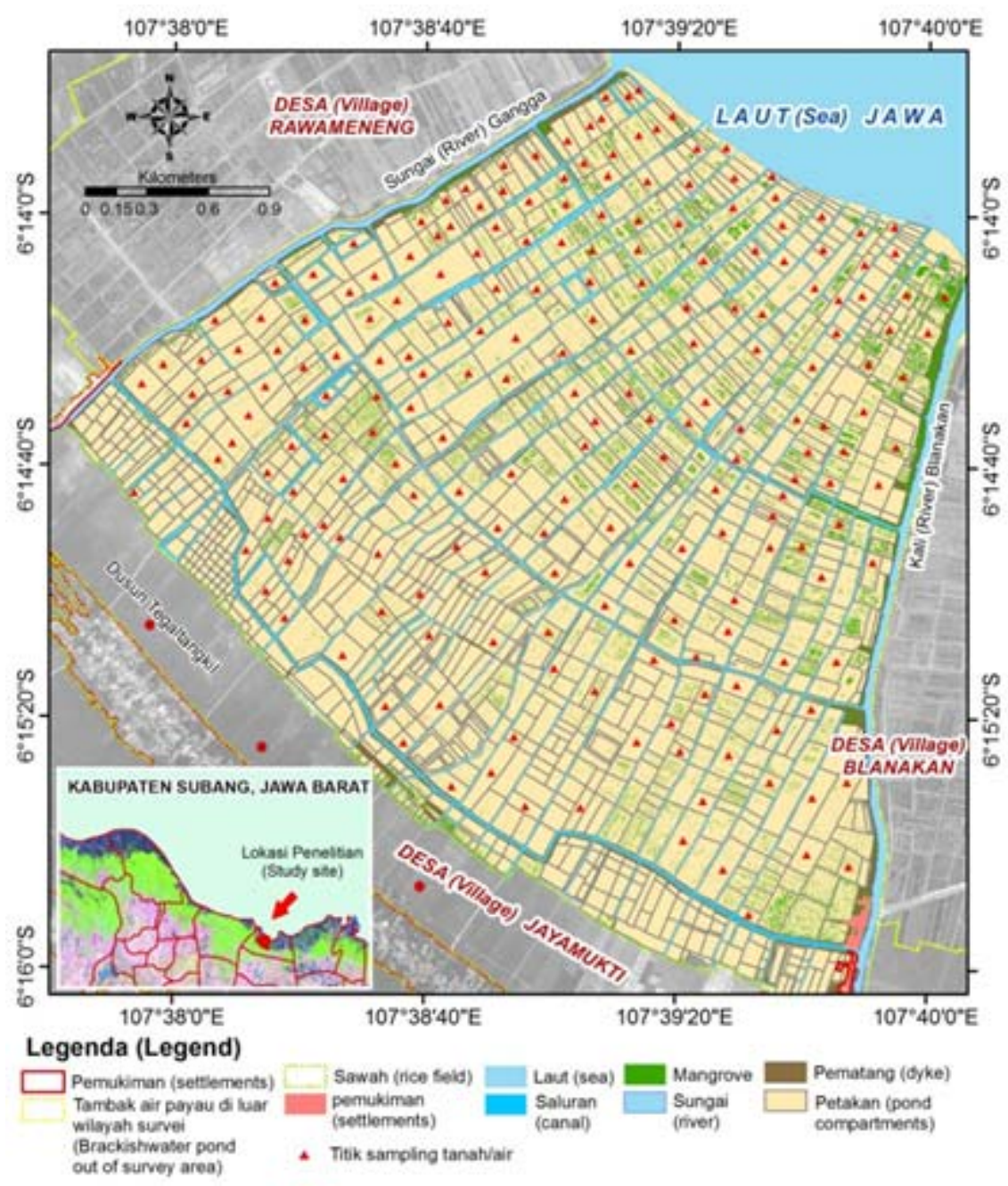

Gambar 1. Lokasi penelitian di kawasan pesisir Kabupaten Subang Provinsi Jawa Barat

Figure 1. Study area in the coastal area of Subang Regency West Java Province

laboratorium berlangsung mulai dari bulan Mei hingga bulan Desember 2014.

\section{Pengumpulan Data}

Secara umum kegiatan penelitian meliputi kegiatan lapang, laboratorium, dan kegiatan pemetaan. Dalam kegiatan tersebut dilakukan: 1) pengambilan contoh tanah untuk 212 titik pada dua kedalaman berbeda (10-20 cm dan 20-40 cm) dengan total 424 sampel, 2) pengukuran insitu kualitas air pada 68 titik; 3) pengukuran dan analisis pasang surut (pasut), dan 4) pengumpulan data sekunder pendukung seperti peta geologi, peta penggunaan lahan, dan data iklim. Lokasi pengambilan sampel secara vertikal dianggap mewakili lapisan tanah asli (natural soils' layer) pada lokasi penelitian. Variabel tanah yang diukur meliputi kandungan bahan organik dan tekstur sedangkan kualitas air meliputi pH, suhu, salinitas, dan oksigen terlarut (DO) diukur secara insitu menggunakan YSI Pro Plus. Penyebaran dan penentuan lokasi titik sampling dilakukan dengan bantuan peta petakan tambak hasil vektorisasi citra satelit worldview-2 akuisisi 5 September 2013 (DigitalGlobe, 2014).

Sampling tanah dilakukan dengan mengaplikasikan kombinasi metode transek (transect method) dan sampling sistematik (systematic sampling method), di mana pada titik-titik tertentu dilakukan penambahan titik sampling di antara dua garis transek dengan tujuan mengupayakan pemerataan distribusi titik sampel dan terpenuhinya kepadatan/jumlah titik sampling untuk metode estimasi (interpolasi) yang diaplikasikan. Secara umum jarak antara dua titik sampling berdekatan pada setiap garis transek sejauh \pm 50 meter (grid size $=50$ meter). 
Pengukuran elevasi lahan tambak dilakukan secara rinci mengikuti metode sipat datar luas dengan menggunakan teodolit tipe Nikon ${ }^{\circledR}$ Digital Theodolite NE-102 (Purworaharjo, 1986). Data elevasi lahan tambak tersebut diikatkan secara lokal dengan data pasang surut (pasut) yang diukur selama 15 piantan (hari pengamatan pasut). Pengamatan pasut dengan interval satu jam dan dimulai pada pukul 00.00 menggunakan palem atau rambu pengamat pasut yang dipasang di perairan laut sekitar kawasan tambak Desa Jayamukti. Bersamaan dengan kegitan ini juga dilakukan evaluasi ketinggian pematang dan dasar saluran di lokasi pertambakan. Untuk tujuan evaluasi tersebut dilakukan pengukuran pada 371 titik yang meliputi 134 titik untuk evaluasi kelayakan elevasi pematang dan 237 titik untuk pengukuran elevasi dasar pelataran dan saluran tambak. Jumlah titik tersebut berbeda dengan total sampel tanah sebagaimana pada Gambar 1, karena hanya dilakukan pada titik tertentu yang dianggap representatif berdasarkan sebaran dan variasi kualitas fisik lahan.

\section{Analisis Data}

Kandungan bahan organik tanah dianalisis dengan metode Walkley and Black (Menon, 1988); sedangkan kelas tekstur tanah dianalisis dengan metode hidrometer (Agus et al., 2006). Data pasut dianalisis dengan metode least square untuk mendapatkan konstanta (komponen) harmonik pasut (Bose et al., 1991). Dari konstanta harmonik pasut tersebut selanjutnya dihitung tipe pasut (berdasarkan tidal form factor, F) untuk perairan di lokasi penelitian menggunakan persamaan 1 (Masselink \& Hugest, 2003).

$$
\mathrm{F}=\frac{K 1+01}{M 2+S 2}
$$

di mana:

F : Bilangan Formzhal (tidal form factor or Formzhal number)

$\mathrm{K}$ : Amplitudo unsur pasut tunggal yang disebabkan oleh gaya tarik matahari (amplitude of luni-solar diurnal component)

01 : Amplitudo unsur pasut tunggal yang disebabkan oleh gaya tarik bulan (amplitude of principal lunar diurnal component)

M2 : Amplitudo unsur pasut ganda utama yang disebabkan oleh gaya tarik bulan (amplitude of principal lunar semi-diurnal component)

S2 : Amplitudo unsur pasut ganda utama yang disebabkan oleh gaya tarik matahari (amplitude of principal solar semi-diurnal component)

Dengan nilai $\mathbf{F}$ ini maka pasut bertipe: A) pasut harian ganda (semi-diurnal) jika $\mathrm{F} \leq 0,25$; $\mathrm{B}$ ) pasut campuran (ganda dominan) jika $0,25<\mathrm{F} \leq 1,5$; C) pasut campuran (tunggal dominan) jika 1,5 $<\mathrm{F} \leq 3$; dan D) pasut harian tunggal (diurnal) $\mathrm{F} \geq 3$. Berdasarkan hasil pengukuran dan perhitungan elevasi lahan dan pasang surut tersebut ditentukan status ketinggian dasar tambak relatif terhadap salah satu bidang referensi pasang surut seperti muka laut rata-rata (MLR) atau mean sea level (MSL).

Untuk lebih memahami variasi spasial karakteristik fisik lahan dilakukan pembuatan peta tematik peubah tanah dan air terpilih dengan metode interpolasi kriging (Burrough \& McDonnell, 1998). Peubah lingkungan yang terpilih tersebut merupakan peubah yang diidentifikasi menjadi faktor pembatas lingkungan terhadap produktivitas dan keberlanjutan tambak silvofishery di lokasi penelitian.

Kriteria kelayakan rekayasa tambak khususnya untuk tambak tradisional (ekstensif) hingga semiintensif umumnya mengikuti kriteria yang dipublikasikan oleh Cruz (1983); Bose et al. (1991); dan Lekang (2007). Perbaikan atau inovasi yang dilakukan dengan metode tersebut adalah dengan memanfaatkan data spasial untuk mengestimasi peubah pada setiap formula dan dalam hal visualisasi spasial hasil analisis. Dan kasus spesifik seperti dasar tambak dan saluran, analisis disesuaikan dengan kriteria teknis tambak silvofishery.

Kelayakan atau efektivitas saluran utama dalam mengalirkan air ke dalam atau keluar sistem pertambakan dievaluasi berdasarkan orientasi mulut saluran terhadap sudut datang gelombang utama yang sampai ke garis pantai dan kapasistas saluran untuk memasok volume air yang dibutuhkan untuk suatu hamparan tambak. Sudut datang gelombang mendekati pantai ditentukan secara sederhana dari hasil viasualisasi citra worldview-2. Sedimentasi yang tinggi yang berakibat pada tertutupnya mulut saluran laut terjadi bilamana mulut saluran dibangun tegak lurus arah datang gelombang. Efektivitas saluran laut untuk memasok volume air yang dibutuhkan juga dianalisis berdasarkan kesesuaian lebar saluran dan kondisi tunggang pasut lokal. Menurut Denila (1976), 1) Jika pasang surut lebih kecil dari 1,5 m dengan luas areal tambak 20 ha, dibutuhkan lebar saluran 7,5 m dan 2) jika pasang surut lebih besar 1,5 $\mathrm{m}$ dengan luas tambak 20 ha dibutuhkan lebar saluran 5,5 m.

Sementara itu, kelayakan elevasi dasar tambak (pond bed/pond bottom) dievaluasi dengan pertama-tama mereferensikan seluruh nilai data pengukuran elevasi lahan dan batimetri pantai (dari hasil pengukuran kemiringan pantai) terhadap datum vertikal pasang surut (MSL). Secara prinsip tunggang pasut lokal (local tidal range) seharusnya mampu secara gravitasi untuk menyediakan volume air yang dibutuhkan untuk pengelolaan tambak pada spesies yang dibudidayakan 
(Cruz, 1983; Bose et al., 1991). Secara umum elevasi dasar tambak dianggap ideal bila dimungkinkan pengeringan tambak sewaktu-waktu bilamana diperlukan dan sebaliknya juga dimungkinkan pengisian air tambak pada kedalaman tertentu sesuai dengan kebutuhan spesies yang dibudidayakan (Cruz, 1983). Dengan dasar tersebut, elevasi dasar tambak yang ideal untuk tambak tradisional (ekstensif) hingga tambak semi-intensif dapat dianggap terletak kurang lebih 0,3 $\mathrm{m}$ dari MSL atau setidaknya $0,2 \mathrm{~m}$ dari zero datum lokal (MLLW) tergantung kondisi lingkungan terutama pasut (Cruz, 1983). Namun demikian untuk tambak silvofishery karakteristik dan desain dasar tambak sedikit berbeda karena dalam satu petakan terdapat dua tipe dasar (pelataran) yakni pelataran petakan budidaya yang identik dengan caren pada tambak tradisonal dan pelataran mangrove. Pada penelitian ini dasar tambak yang dimaksud mengacu pada plataran caren, akan tetapi dalam perhitungan volume air plataran mangrove juga ikut dipertimbangkan.

Untuk menghitung ketinggian pematang ideal digunakan data iklim dan hidrologi lima tahunan, meliputi curah hujan dan ketinggian banjir maksimum. Data tersebut didapatkan pada stasiun klimatologi Klas I Darmaga Bogor, data real-time estimasi curah hujan dari website HyDIS-G-WADI Geoserver (http:// hydis.eng.uci.edu/gwadi/) dan laporan hasil kajian pengembangan minapolitan di pantura Kabupaten Subang (Bappeda-Kabupaten Subang, 2010). untuk mendekati kondisi alami pada lokasi penelitian. Ketinggian ideal pematang tambak selanjutnya dihitung berdasarkan formula berikut (Cruz, 1983; Bose et al., 1991).

$$
\begin{aligned}
& \mathrm{HP}=\frac{(H A T-G S)+M F+F B}{1-\% S} \\
& \mathrm{HS}=\frac{(H S T-G S)+M R+F B}{1-\% S}
\end{aligned}
$$

$$
\begin{aligned}
\text { di mana: } & \\
\mathrm{HP}= & \text { ketinggian pematang primer (utama) } \\
\mathrm{HS}= & \text { ketinggian pematang sekunder } \\
\mathrm{HAT}= & \text { highest astronomical tide (pasang tertinggi karena } \\
& \text { pengaruh astronomis) } \\
\mathrm{HST}= & \text { highest spring tide (pasang tertinggi saat purnama) } \\
\mathrm{GS}= & \text { ketinggian permukaan tanah dihitung dari MSL } \\
\mathrm{MF}= & \text { ketinggian banjir maksimum selama } 10 \text { tahun terakhir } \\
\mathrm{MR}= & \text { curah hujan maksimum dalam } 24 \text { jam } \\
\mathrm{FB}= & \text { ketinggian "free board" } \\
\% \mathrm{~S}= & \text { persentase penyusutan tanah pematang (Alcantara, } \\
& 1982 ; \text { Menasveta, 1982; Bose et al., 1991) }
\end{aligned}
$$

Analisis deskriptif kualitas tanah dan air diolah menggunakan software statistik SPSS versi 17 dan
Microsoft Excel 2007. Untuk analisis data spasial digunakan software ArcGIS 10.0, Map Info 9.0. dan SURFER 8.0.

\section{HASIL DAN BAHASAN}

\section{Karakteristik Tambak Silvofishery di Lokasi Penelitian}

Berdasarkan peta geologi lembar Pamanukan (12096) yang dikeluarkan oleh Pusat Survai Geologi (Abidin \& Sutrisno, 2011), kualitas tanah tambak yang berjarak sekitar 2-3 km dari garis pantai dicirikan dengan tekstur tanah liat yang utamanya merupakan endapan sedimen yang diangkut dari sungai air tawar yang mengalir sepanjang tahun. Green belt berupa mangrove di sepanjang pantai umumnya didominasi jenis api-api (Avicenia sp.) dan sebagian kecil bakau (Rhizopora sp.). Lebar bentangan mangrove ini berkisar antara 50-70 m. Rhizopora umumnya ditemukan pada green belt sungai dengan lebar bentangan berkisar antara 5-7 m.

Luas hamparan tambak di Desa Jayamukti pada saat pelaksanaan penelitian mencapai 900 ha. Berdasarkan peta petakan tambak dari hasil vektorisasi citra worldview-2 diketahui bahwa total luasan hamparan tambak tersebut terdiri atas sekitar 1.370 unit atau petakan tambak. Status kepemilikan sebagian besar (700 ha) adalah milik Perhutani, dan sebagian kecil (200 ha) adalah tanah milik masyarakat. Bentuk petakan tambak tradisional merupakan tipe satu tahapan yaitu hanya berupa petakan pembesaran, dengan luas petakan 0,5-8 ha; dengan luas kepemilikan dominan adalah 2 ha. Jaringan saluran tambak terdiri atas sejumlah saluran-saluran membujur yang berhubungan dengan laut (selanjutnya disebut sebagai saluran laut) dan saluran-saluran melintang yang berhubungan dengan kedua buah sungai di sebelah Barat dan Timur areal pertambakan. Di antara saluran-saluran tersebut terhampar blok-blok tambak yang cukup rapi, dengan bentuk petakan tambak persegi panjang. Tambak silvofishery di lokasi ini dicirikan dengan proporsi tanaman mangrove yang rendah hingga sedang dengan kisaran antara 30\%-70\% luas setiap petakan.

Model penampang tambak silvofishery di kawasan pertambakan tersebut merupakan kombinasi pola empang parit dan empang parit yang disempurnakan (Bengen, 2002). Lebar caren rata-rata 4-6 m dengan kedalaman rata-rata $0,75 \mathrm{~m}$. Kedalaman pelataran berkisar 5-20 cm, dan sebagian besar arealnya ditumbuhi Avicenia. Dengan perakaran napas cukup lebat di sekeliling pokok batangnya, tumbuhan ini membuat kedalaman pelataran di sini lebih dangkal hingga kurang sesuai untuk ikan ukuran besar. Setiap petak tambak dilengkapi dengan pintu air tipe sluice terbuat dari bambu atau kayu, dilengkapi dengan struktur pemasangan impes terbuat dari bambu. Air 
tambak cukup subur, ditandai dengan berkembangnya plankton yang cukup moderat, dan sebagian besar petakan ditumbuhi klekap (Bappeda-Kabupaten Subang, 2010).

Air tambak yang digunakan sebagai media budidaya dipasok dari hasil percampuran air laut dan air tawar. Petakan tambak dan pasokan air laut berasal dari 21 saluran (kalen) laut yang terdiri atas Kalen Tabri, Kalen Sawah, Kalen Diwang, Kalen Kasim, Kalen Dastiwan, Kalen Sedong, Kalen Rais, Kalen Asem, Kalen Asim, Kalen Kelapa, Kalen Droak, Kalen Ardiwan, Kalen Kuncung, Kalen Cibening, Kalen Tarsiman, Kalen Carman, Kalen Gendut, Kalen Maskin, Kalen Sona, Kalen Karta, dan Kalen H. Daim. Panjang kalen tersebut bervariasi dari $1.500 \mathrm{~m}$ hingga $3.750 \mathrm{~m}$. Sedangkan air tawar utamanya dipasok oleh tiga saluran induk yakni Kali Malang 1, Kali Malang 2, dan Kali Malang 3 yang menghubungkan Sungai Blanakan dan Sungai Gangga.

\section{Kondisi Pasang Surut}

Pada Tabel 1 diketahui bahwa karakteristik pasut di Kecamatan Blanakan lebih mirip dengan karakteristik pasut di Kabupaten Cirebon. Berdasarkan nilai konstanta harmonik pasut dan grafik pasut pada Tabel 1 tersebut diketahui tipe pasut untuk kawasan pertambakan adalah tipe 'campuran condong ke semidiurnal' (Mixed-type, semi-diurnal dominance) dengan nilai $F=1,02$. Dengan tipe pasut demikian pergantian air di wilayah umumnya dapat dilakukan dua kali dalam 24 jam. Hasil analisis data pasut tersebut lebih lanjut menunjukkan tunggang pasut (tidal range) yang relatif kecil. Tunggang pasut tertinggi hanya sekitar 0,6 m dengan rataan pasang tinggi sebesar $\pm 0,45 \mathrm{~m}$ pada saat purnama dan bulan mati (spring tide), dan tunggang pasut yang lebih rendah sekitar $\pm 0,10 \mathrm{~m}$ didapatkan pada saat pasang perbani (neap tide) seperti yang terlihat pada Gambar 2. Dengan tunggang pasut yang kecil (kurang dari $1 \mathrm{~m}$ ) demikian tentunya akan menjadi faktor pembatas secara teknis (Poernomo, 1992). Secara umum kisaran pasang surut yang ideal untuk tambak budidaya udang adalah antara 1,5 dan 2,5 m. Daerah pantai dengan kisaran pasut kurang dari $1 \mathrm{~m}$ sangat sulit untuk pengisian maupun pengeluaran air tambak secara gravitasi. Berdasarkan hasil observasi lapang diketahui bahwa meskipun terdapat saluran pemasok air laut dan air tawar, proses pemasukan air ke dalam petakan tambak secara optimal hanya dimungkinkan dengan bantuan pompa.

\section{Kualitas Tanah dan Air Tambak di Lokasi Penelitian}

Hasil analisis statistik deskriptif untuk data kualitas tanah ditampilkan pada Tabel 2. Kualitas tanah di lokasi penelitian secara umum tergolong cukup baik untuk mendukung kegiatan rekayasa dan pengelolaan tambak. Kelas tekstur tanah tambak di lokasi penelitian dapat dikelompokkan dari yang paling dominan hingga paling kecil yaitu liat $(45,0 \%)$, lempung berliat $(29,7 \%)$, lempung $(15,3 \%)$, lempung berpasir $(3,6 \%)$, lempung liat berpasir $(2,7 \%)$, liat berpasir $(1,8 \%)$, debu $(0,9 \%)$, dan lempung berdebu $(0,9 \%)$. Menurut Ilyas et al. (1987), tekstur tanah yang baik untuk tambak adalah: liat, lempung berliat, lempung liat berdebu, lempung berdebu, lempung, dan lempung liat berpasir.

Tabel 1. Perbandingan nilai konstanta harmonik utama dan tipe pasut antara lokasi penelitian dengan konstanta harmonik pasut beberapa lokasi di sekitarnya

Table 1. The comparison of major tide harmonic constituents' amplitude and tide types between the study site and neighbouring sites

\begin{tabular}{lccc}
\hline $\begin{array}{l}\text { Konstanta harmonik } \\
\text { Harmonic constituents }\end{array}$ & Tanjung Priok & Cirebon & Subang \\
\hline M2, Principal lunar & 5 & 16 & 6,3 \\
S2, Principal solar & 4 & 10 & 11,65 \\
N2, Larger lunar elliptic & 1 & 6 & 0,52 \\
K2, Luni-solar semi-diurnal & 1 & 5 & 14,57 \\
K1, Luni-solar diurnal & 29 & 14 & 13,26 \\
O1, Principal lunar diurnal & 13 & 5 & 5,05 \\
P1, Principal solar diurnal & 10 & $5,6,16$ \\
Formzhal (F) & 4,66 & 0,73 & 1,02 \\
Tipe pasut & Harian (Diurnal) & Campuran: condong & Campuran: condong \\
Tide type & & Mixed-type, & ke semi-diurnal \\
& & prevailing to semi-diurnal & Mixed-type, \\
\end{tabular}




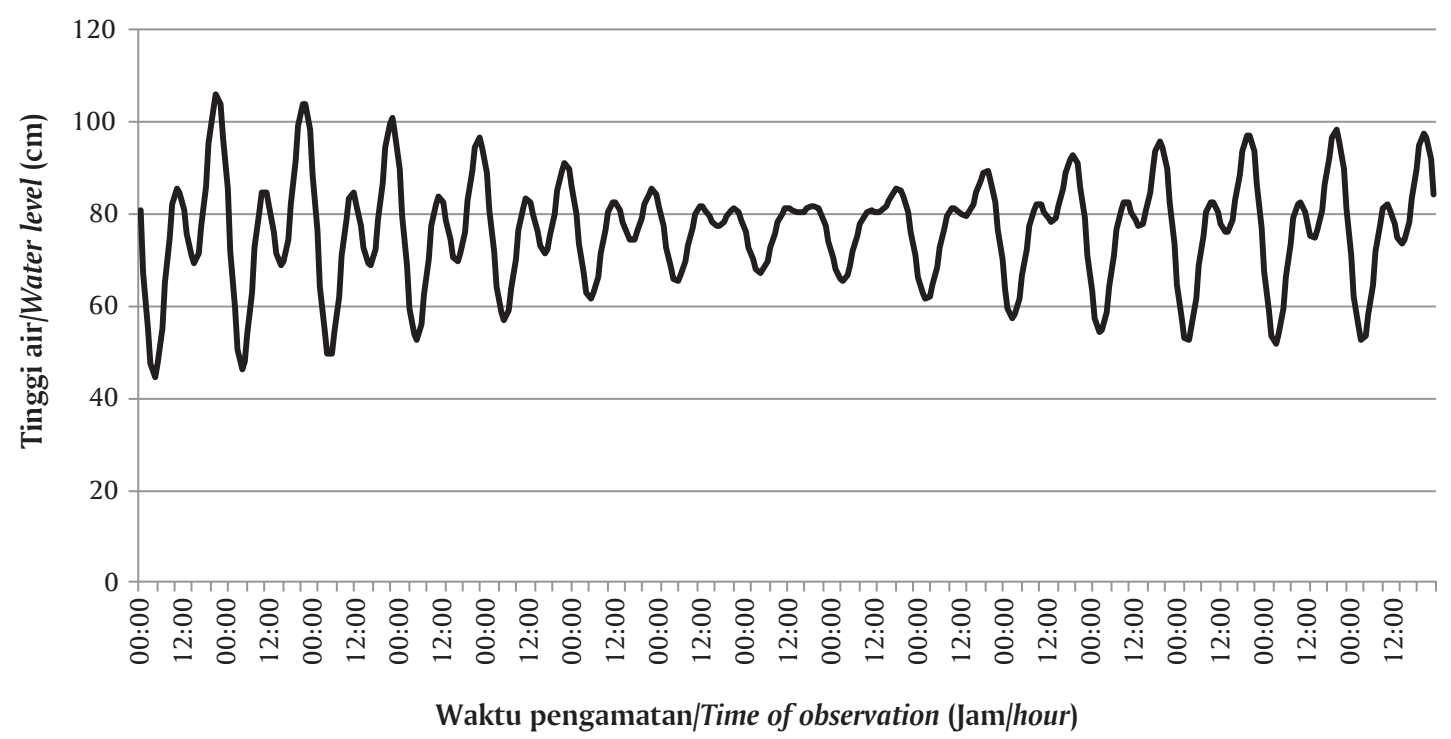

Gambar 2. Grafik pasut untuk perairan di sekitar pertambakan Desa Jayamukti, diukur dari 19 September hingga 3 Oktober 2014

Figure 2. Tide chart of coastal water nearby farming area in Jayamukti Village recorded from 19 September to 3 October 2014

Dengan demikian tekstur tanah di lokasi penelitian tergolong baik dan secara teknis dapat mendukung rekayasa tambak maupun pengelolaannya. Tekstur tanah tambak sangat berpengaruh terhadap porositas dan pertumbuhan klekap yang dapat menjadi salah satu makanan alami bagi ikan dan udang. Tambak dengan tanah bertekstur kasar seperti pasir dan pasir berlempung memiliki tingkat porositas yang tinggi, sebagai akibat tambak tidak bisa menahan air. Tanah dengan kandungan liat minimal 20\%-30\% terbukti efektif dalam menahan peresapan ke samping. Kisaran nilai bahan organik di kawasan pertambakan ini adalah $0,43-6,08(2,77 \pm 1,00)$. Bahan organik di tambak dapat berpengaruh terhadap kestabilan tanah, konsumsi oksigen, sumber unsur hara, dan kesesuaian habitat dari dasar tambak. Dengan pertimbangan tekstur dan kisaran optimum tersebut diatas maka kandungan bahan organik pada kawasan pertambakan ini masih tergolong baik untuk kegiatan budidaya khususnya untuk konstruksi pematang tambak.

Data kualitas air yang diukur secara insitu ditampilkan pada Tabel 3. Nilai suhu, pH, dan oksigen terlarut (DO) air tambak pada umumnya masih dalam kategori layak untuk budidaya tambak. Suhu air kawasan pertambakan berkisar antara $25^{\circ} \mathrm{C}-32^{\circ} \mathrm{C}$ $(31,78 \pm 2,45)$. Suhu air yang layak untuk budidaya

Tabel 2. Data kualitas tanah unit tambak di Desa Jayamukti Kecamatan Blanakan Kabupaten Subang Provinsi Jawa Barat (rataan \pm standar deviasi, $\mathrm{n}=424$ )

Table 2. Soil quality data collected from pond units in Jayamukti Village Blanakan Sub-District Subang Regency West Java Province (mean \pm standard of deviation, $n=424$ )

\begin{tabular}{lcc}
\hline \multicolumn{1}{c}{$\begin{array}{c}\text { Peubah } \\
\text { Variable }\end{array}$} & $\begin{array}{c}\text { Nilai } \\
\text { Value }\end{array}$ & $\begin{array}{c}\text { Nilai yang layak } \\
\text { Suitable value }\end{array}$ \\
\hline $\begin{array}{l}\text { Bahan organik } \\
\text { Organic matter (\%) }\end{array}$ & $2.77 \pm 1.00$ & $0.8-8$ \\
$\begin{array}{l}\text { Kelas tekstur } \\
\text { Textural classes }\end{array}$ & $\begin{array}{c}\text { Liat (clay), lempung berliat (clay loam), lempung } \\
\text { (loam), lempung berpasir (sandy loam), lempung liat } \\
\text { berpasir (sand clay loam), liat berpasir (sandy clay), } \\
\text { debu (silt), dan lempung berdebu (silty loa } \mathrm{m})\end{array}$ & $\begin{array}{c}\text { Liat (clay), lempung berliat (clay loam), lempung } \\
\text { liat berdebu (silt clay loam), lempung berdebu } \\
\text { (silty loam), lempung (loam), dan lempung liat } \\
\text { berpasir (sand clay loam) }\end{array}$ \\
\hline
\end{tabular}

Sumber (Sources): $\quad$ * Boyd \& Wood (2002); Ilyas et al. (1987); Sammut (2002) 
udang windu berkisar antara $26^{\circ} \mathrm{C}-32^{\circ} \mathrm{C}$ dan optimumnya antara $29^{\circ} \mathrm{C}-30^{\circ} \mathrm{C}$ (Poernomo, 1988), sehingga suhu air di kawasan tersebut masih dalam kategori yang layak. Kisaran $\mathrm{pH}$ yang baik untuk udang windu adalah 7,5-8,7 dengan nilai optimum 8,0-8,5 (Poernomo, 1992). Menurut Swingle (1968), pada umumnya $\mathrm{pH}$ air yang baik bagi organisme akuatik adalah 6,5-9,0; pada pH 9,5-11,0; dan 4,0-6,0 mengakibatkan produksi rendah dan jika lebih rendah dari 4,0 atau lebih tinggi 11,0 akan meracuni ikan. Nilai pH $(8,9 \pm 0,3)$ masih dalam kategori yang layak untuk budidaya udang dan ikan. Meskipun di beberapa petakan tambak terdapat nilai DO yang lebih rendah dari dua, namun demikian secara umum nilai DO masih dalam kategori yang layak untuk mendukung kegiatan budidaya. Peubah kualitas air yang nampaknya menjadi faktor pembatas kegiatan budidaya tambak di kawasan ini adalah salinitas yang berkisar antara 7-65 (35,14 \pm 12,88). Udang windu, udang vaname, bandeng, dan rumput laut merupakan organisme eurihalin, namun karena dibudidayakan untuk tujuan komersial, kisaran salinitas yang optimum perlu dipertahankan. Udang windu mampu menyesuaikan diri terhadap salinitas 3-45 ppt (Tseng, 1987 dalam Poernomo, 1988), namun untuk pertumbuhan optimum diperlukan salinitas 1525 ppt (Poernomo, 1988). Udang vaname umumnya tumbuh optimum pada salinitas 15-20 ppt (Bray et al., 1994).

\section{Kelayakan Rekayasa Tambak}

Rekayasa tambak yang meliputi desain dan konstruksi merupakan titik awal berhasil atau gagalnya kegiatan budidaya organisme akuatik di tambak.
Kesalahan dalam mendesain konstruksi tambak adalah awal dari kegagalan usaha budidaya yang akan dilakukan. Desain dan konstruksi tambak meliputi: layout petakan, pematang, saluran, dan dasar tambak. Karena tambak tersebut dikelola dengan sistem silvofishery maka kelayakan layout tambak yang biasanya dievaluasi menurut orientasi dari arah angin utama/ dominan tidak dipertimbangkan. Keberadaan mangrove di tengah petakan tambak dapat menjadi pelindung bangunan fisik tambak dan merupakan sumber nutrien utama untuk kegiatan budidaya tambak di lokasi penelitian. Hasil evaluasi kelayakan berdasarkan aspek rekayasa tambak berikut hanya difokuskan pada kesesuaian dasar tambak, ketinggian pematang, dan efektivitas saluran tambak.

\section{Dasar Tambak}

Gambar 3 menunjukkan karakteristik elevasi dasar tambak budidaya (dasar atau pelataran caren) dengan referensi MSL. Nilai negatif menunjukkan elevasi berada di bawah muka laut rata-rata. Berdasarkan informasi spasial dari nilai elevasi tambak pada Gambar 3 tersebut diketahui bahwa 78\% dari seluruh petakan tambak memiliki elevasi dasar lebih rendah jika dibandingkan elevasi ideal tambak tradisional (ekstensif) dan semi-intensif. Untuk elevasi tambak tradisional plus dan semi-intensif ketinggian dasar tambak sebaiknya terletak di antara rataan pasang tinggi (MHHW) dan rataan pasang rendah (MLLW) atau dengan kata lain berada di sekitar ketinggian mean sea level (MSL) ( \pm 0,15 m dari MSL) (Poernomo, 1992). Ketinggian dasar tambak tersebut disarankan berdasarkan kedalaman air yang dikehendaki dan

Tabel 3. Data kualitas air unit tambak di Desa Jayamukti Kecamatan Blanakan Kabupaten Subang Provinsi Jawa Barat (rataan \pm standar deviasi)

Table 3. Water quality data of pond units in Jayamukti Village Blanakan Sub-District Subang Regency West Java Province (mean \pm standard of deviation)

\begin{tabular}{|c|c|c|}
\hline $\begin{array}{l}\text { Peubah } \\
\text { Variable }\end{array}$ & $\begin{array}{l}\text { Nilai } \\
\text { Value }\end{array}$ & $\begin{array}{c}\text { Nilai yang layak } \\
\text { Suitable value }\end{array}$ \\
\hline \multicolumn{3}{|c|}{ Pengukuran insitu (n= 219) } \\
\hline $\begin{array}{l}\text { Salinitas } \\
\text { Salinity (ppt) }\end{array}$ & $35.14 \pm 12.88$ & $5-35$ \\
\hline $\begin{array}{l}\text { Suhu } \\
\text { Temperature }\left({ }^{\circ} \mathrm{C}\right)\end{array}$ & $31.78 \pm 2.45$ & $21-32$ \\
\hline $\mathrm{pH}$ & $8.94 \pm 0.37$ & $6.5-9.0$ \\
\hline $\begin{array}{l}\text { Oksigen terlarut } \\
\text { Disolved oxygen (mg/L) }\end{array}$ & $5.33 \pm 1.77$ & $2-10$ \\
\hline
\end{tabular}



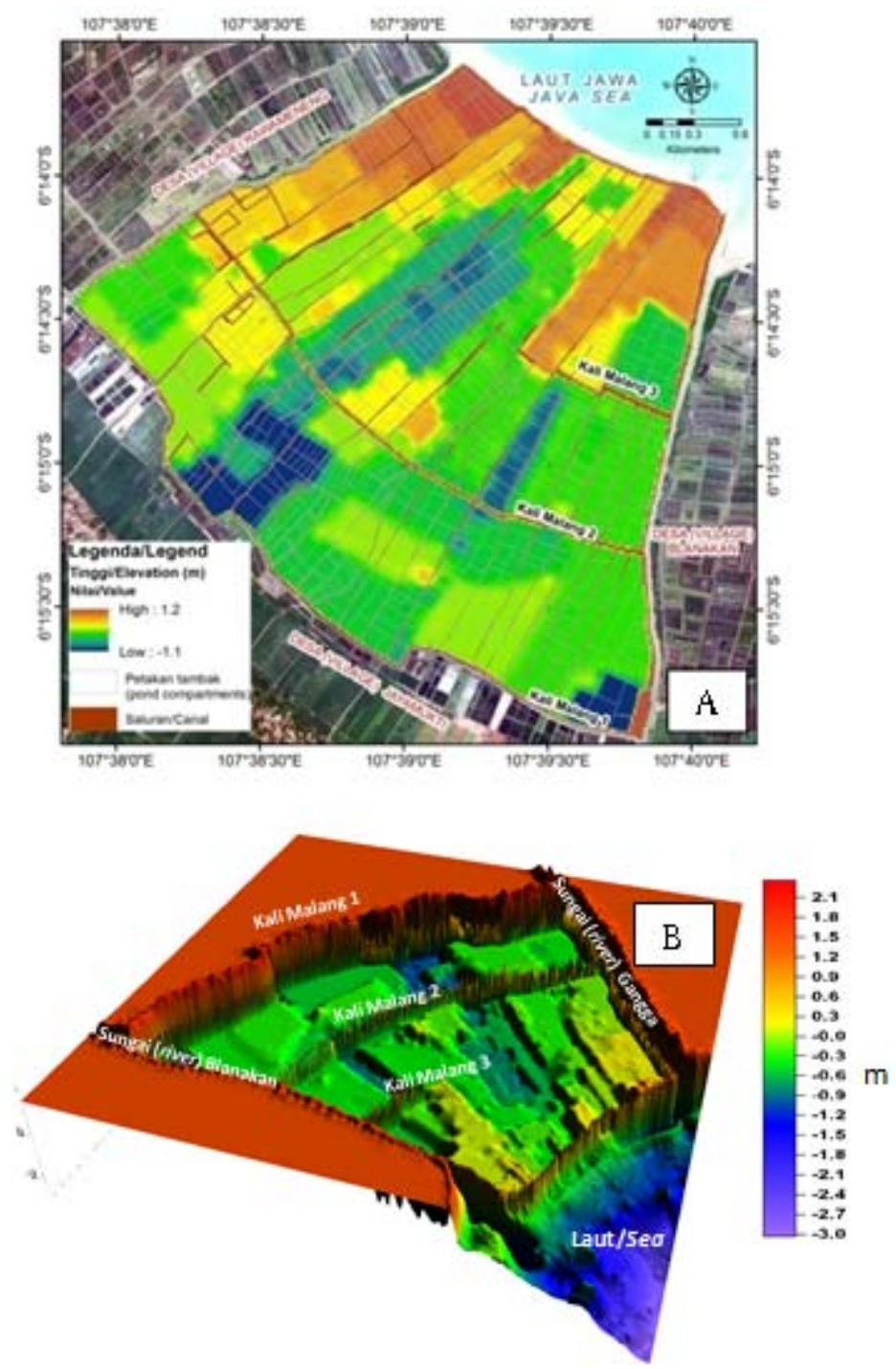

Gambar 3. Peta elevasi dasar tambak dengan referensi MSL-lokal $(\mathrm{A}=2$ - $\mathrm{D}$ view dan $\mathrm{B}=3$ - $\mathrm{D}$ view)

Figure 3. Map of pond bed elevation with reference to locally calculated MSL $(A=2-D$ view and $B=3-D$ view $)$

pertimbangan ekonomis konstruksi. Namun demikian kondisi elevasi dasar yang lebih rendah pada tambak silvofishery masih dapat dipahami, antara lain dengan pertimbangan susahnya pemasukan air lewat saluran laut untuk mendapatkan volume yang sesuai dengan kebutuhan. Ketersediaan dan pergantian air meskipun dalam volume kecil juga dimaksudkan untuk menjaga pertumbuhan dan kelangsungan mangrove dalam petakan yang pada habitat alaminya menyesuaikan diri dengan siklus pasut. Dengan karakteristik demikian sebagian besar petakan tambak tersebut jarang dikeringkan secara sempurna sebagaimana yang umumnya dilakukan pada pengelolaan tambak ekstensif. Input nutrien diharapkan utamanya berasal dari pergantian air lewat saluran dan nutrien yang dari pelataran yang ditumbuhi mangrove, dan bukan dari hasil pengelolaan tanah dasar.

Efektivitas dan kelayakan dimensi dasar tambak dapat dilihat lebih jauh dari kemampuannya untuk menyediakan volume air yang dibutuhkan untuk menjaga kualitas air. Volume air yang tersedia tersebut antara lain harus dengan kadar salinitas yang masih layak untuk berbagai budidaya komoditas air payau dan sebagai media bagi pertumbuhan ikan/udang liar. Berdasarkan hasil kajian untuk pengembangan minapolitan di pantura Kabupaten Subang yang dilakukan oleh Bappeda Kabupaten Subang (2010), lebar caren yang mejadi media budidaya di Desa Jayamukti pada ditetapkan antara 4-6 m dengan kedalaman rata-rata $0,75 \mathrm{~m}$ dan kedalaman rata-rata 
pelataran mangrove $0,125 \mathrm{~m}(0,05-0,20 \mathrm{~m})$. Jika data ini dipadukan dengan luas total petakan budidaya 4.908.000 $\mathrm{m}^{2}$ (setengah luas total petakan karena 50\% digunakan untuk mangrove) maka volume air total yang dibutuhkan idealnya sebesar $3.435 .600 \mathrm{~m}^{3}$. Volume air ini tidak termasuk volume air pelataran mangrove yang senantiasa berganti mengikuti pola air pasut. Hasil analisis data kedalaman air di petakan budidaya saat survai dilakukan menunjukkan bahwa air hanya mampu dipertahankan pada kedalaman ratarata $0,42 \mathrm{~m}$ atau mengalami penyusutan sebesar $40 \%$ akibat sedimentasi dari yang kondisi awal, sehingga volume air yang dapat ditampung hanya sekitar $2.061 .360 \mathrm{~m}^{3}$ atau hanya sekitas $60 \%$ dari total yang dibutuhkan. Dari total $60 \%$ tersebut, $>50 \%$ petakan akan mengalami kesulitan pergantian air laut untuk mendapatkan salinitas ideal sehubungan dengan kurang efektifnya fungsi saluran laut.

Pada musim kemarau salinitas air tambak pada petakan-petakan yang dekat dengan laut dapat mencapai 65 ppt, sedangkan untuk petakan-petakan tambak yang jauh dari pantai berkisar 7-20 ppt (tetapi mencapai 0 pada saat musim hujan) (Gambar 4). Dengan demikian pada kondisi rekayasa dan manajemen tambak yang ada peubah salinitas air tambak dapat menjadi faktor pembatas baik di musim hujan maupun di musim kemarau.

\section{Pematang Tambak}

Tabel 4 menyajikan status kelayakan tinggi pematang tambak eksisting yang meliputi pematang primer dan sekunder dibandingkan dengan tinggi pematang ideal hasil kalkulasi dengan persamaan 1 dan 2. Tinggi ideal pematang primer dan pematang sekunder dihitung masing-masing $1,35 \mathrm{~m}$ dan 1,02 meter dari MSL lokal, dengan asumsi nilai freeboard (FB) sebesar 0,3 $\mathrm{m}$ (hasil observasi lapang dan komunikasi personal dengan staf Dinas Kelautan dan Perikanan Kabupaten Subang, 2014), ketinggian banjir maksimum 0,5 $\mathrm{m}$ dan tinggi curah hujan maksimum dalam 24 jam sebesar 0,3 m (hasil analisis data curah hujan BMKG-Darmaga, 2014; HyDIS-G-WADI, 2014; Bappeda-Kabupaten Subang, 2010). Selisih tinggi antara pematang primer ideal dengan pematang primer eksisting berkisar -0,25 hingga $-1,13 \mathrm{~m}$ dan pematang sekunder sekitar -0,34 hingga -0,89. Informasi perbandingan tinggi pematang ini menjadi indikator bahwa jika terjadi kondisi ekstrem (pasang tinggi dan banjir ekstrem) dapat dipastikan bahwa seluruh wilayah tambak tersebut akan terendam.

\section{Saluran Tambak}

Saluran tambak dalam suatu unit pertambakan berfungsi menghubungkan antara sumber air baik langsung dari laut maupun melalui sungai dengan unit

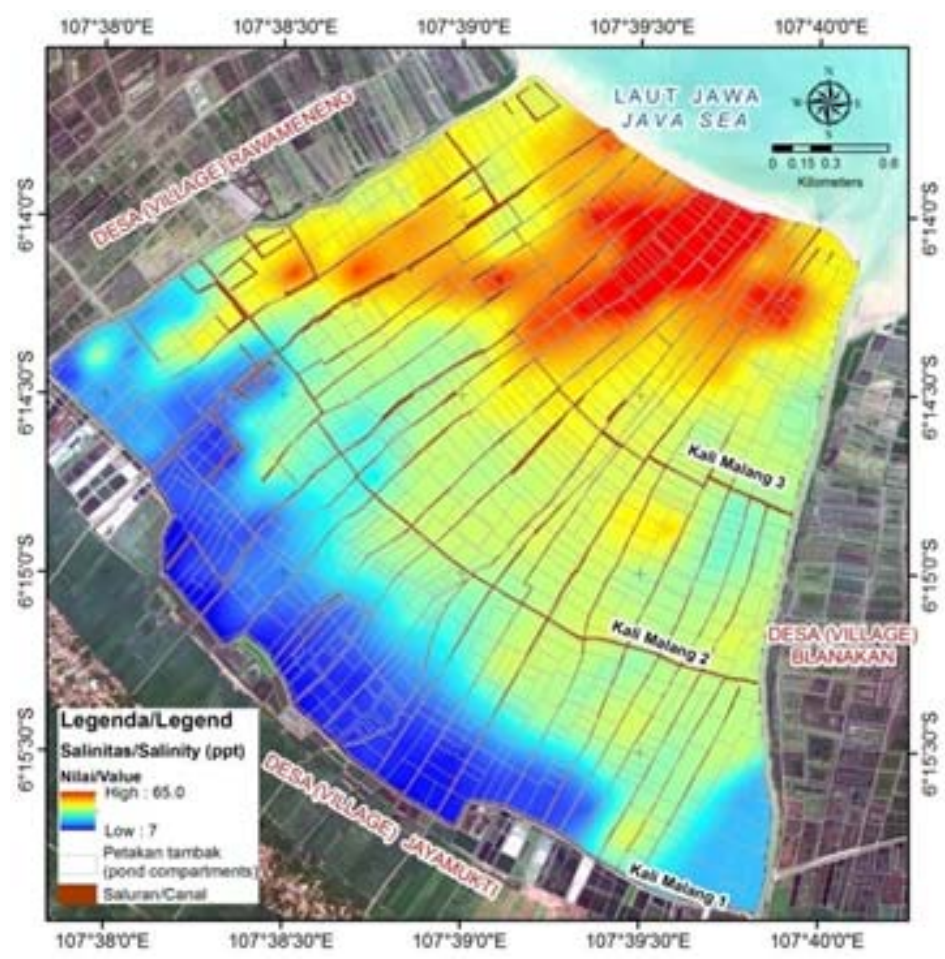

Gambar 4. Peta distribusi nilai salinitas air tambak di Desa Jayamukti Kecamatan Blanakan Kabupaten Subang Provinsi Jawa Barat

Figure 4. Distribution map of salinity values of pond water in Jayamukti Village Blanakan Sub-District Subang Regency West Java Province 
Tabel 4. Status ketinggian pematang tambak eksisting dibandingkan dengan hasil kalkulasi tinggi pematang ideal

Table 4. The status of currently dyke height compared to calculated ideal dyke height

\begin{tabular}{|c|c|c|c|}
\hline $\begin{array}{l}\text { Kode pematang } \\
\text { Code of dykes }\end{array}$ & $\begin{array}{l}\text { Tinggi pematang } \\
\text { eksisting dari MSL } \\
\text { Average currently } \\
\text { dyke height from MSL } \\
\text { (m) }\end{array}$ & $\begin{array}{l}\text { Tinggi pematang } \\
\text { ideal dari MSL } \\
\text { Ideal dyke } \\
\text { height from MSL } \\
\text { (m) }\end{array}$ & $\begin{array}{l}\text { Selisih tinggi } \\
\text { rata-rata } \\
\text { Average difference of } \\
\text { height from MSL } \\
\text { (m) }\end{array}$ \\
\hline \multicolumn{4}{|c|}{ Pematang primer (Primary dyke) } \\
\hline Kl. Tabri $(\mathrm{n}=1)$ & 110 & \multirow{6}{*}{1.35} & -0.25 \\
\hline Kl. Kasim $(n=1)$ & 87 & & -0.48 \\
\hline Kl. Rais $(\mathrm{n}=1)$ & 36 & & -0.99 \\
\hline Kl. Kelapa $(\mathrm{n}=1)$ & 65 & & -0.70 \\
\hline Kl. Cibening $(n=1)$ & 77 & & -0.58 \\
\hline Kl. Gendut $(\mathrm{n}=1)$ & 22 & & -1.13 \\
\hline \multicolumn{4}{|c|}{ Pematang sekunder (Secondary dyke) } \\
\hline Kl. Tabri $(n=25)$ & $0.67 \pm 0.30$ & \multirow{6}{*}{1.02} & -0.34 \\
\hline Kl. Kasim $(n=24)$ & $0.49 \pm 0.20$ & & -0.53 \\
\hline Kl. Rais $(n=25)$ & $0.13 \pm 0.21$ & & -0.89 \\
\hline Kl. Kelapa $(\mathrm{n}=20)$ & $0.16 \pm 0.39$ & & -0.62 \\
\hline Kl. Cibening $(\mathrm{n}=21)$ & $0.64 \pm 0.31$ & & -0.37 \\
\hline Kl. Gendut (n=13) & $0.35 \pm 0.11$ & & -0.66 \\
\hline
\end{tabular}

pertambakan. Ukuran dan lebar saluran disesuaikan dengan kondisi pasang surut di lokasi pertambakan dan luas area yang akan diairi, sedangkan dalamnya saluran primer dibuat rata-rata $15 \mathrm{~cm}$ di atas garis surut terendah atau zero datum. Saluran mempunyai peranan penting dalam proses penyediaan kuantitas dan kualitas yang cukup dalam suatu kawasan pertambakan atau satu unit tambak, oleh karenanya sebaiknya saluran memenuhi tiga persyaratan yaitu: 1) jika memungkinkan agar saluran dibuat lurus agar proses resirkulasi air lancar; 2) saluran harus bebas dari endapan sedimen, dan 3) saluran harus bebas dari sampah-sampah dan rerumputan. Jika syarat tersebut tidak terpenuhi tentunya akan mengganggu proses pengelolaan air sebagai penentu keberhasilan budidaya organisme akuatik.

Hasil observasi lapang pada 6 kalen laut (Kl. Tabri, Kl. Kasim, Kl. Rais, Kl. Kelapa, Kl. Cibening, dan Kl. Gendut) secara umum menunjukkan bahwa $>80 \%$ mulut kalen laut tersebut tertutup karena sedimentasi di mulut saluran. Sedimen yang terangkut melalui kedua sungai air tawar yang mengapit kawasan tambak selanjutnya tertahan dan terdeposisi oleh ombak yang datang hampir tegak lurus dengan mulut kalen laut tersebut. Di samping itu, longsoran dinding pematang saluran primer laut tersebut yang dibangun dari tanah hasil sedimentasi umumnya terakumulasi di dasar saluran mengakibatkan pendangkalan sepanjang saluran. Pola pengembangan tanah tumbuh yang tidak terkontrol dan kurang mendapatkan bimbingan teknis ikut menurunkan efektivitas fungsi saluran utamanya saluran laut tersebut, karena umumnya lebar saluran dibuat menjadi lebih sempit.

Hasil pengukuran elevasi dasar saluran menunjukkan bahwa ketinggian dasar saluran di lokasi penelitian umumnya $>30 \mathrm{~cm}$ dari zero datum sehingga dianggap tidak efektif karena pasokan air optimal hanya dimungkinkan pada pasang tinggi. Berdasarkan data nominatif pemilik tambak di Desa Jaya Mukti (KUD-MBS, 2013) awalnya lebar 21 saluran laut per Maret 2013 berkisar antara 3-8 m (rata-rata$5,5 \mathrm{~m}$ ) dengan kedalaman saat rata-rata pasang tinggi 0,2-1,25 m (rata-rata $0,72 \mathrm{~m}$ ), namun demikian berdasarkan data hasil vektorisasi citra worldview-2 yang diverifikasi data lapang menunjukkan lebar saluran eksisting berkisar 3-7 m dengan kedalaman pada saat rata-rata pasang tinggi $0-0,7 \mathrm{~m}$ (rata-rata $0,35 \mathrm{~m}$ ) atau mengalami penyusutan kedalaman air saluran rata-rata sekitar $48 \%$ dalam kurun waktu satu tahun. Masing-masing saluran laut tersebut diperuntukkan untuk menyuplai rata-rata total luas petakan 40 ha. Menurut Denila (1976), untuk nilai tunggang pasut $<1,5 \mathrm{~m}$ dibutuhkan lebar salurannya $7,5 \mathrm{~m}$ untuk total luas petakan 20 ha. Selanjutnya dengan total luas permukaan saluran $270.000 \mathrm{~m}^{2}$ dan kedalaman air disaluran rata-rata 0,35 m maka 
volume air yang tersedia di saluran setiap harinya sebesar $94.500 \mathrm{~m}^{3}\left(189.000 \mathrm{~m}^{3} /\right.$ hari untuk pasut semidiurnal). Dan jika pengambilan air dilakukan selama lima hari pada setiap siklus pasut (15 hari) maka saluran eksisting hanya mampu menyediakan sekitar 945.000 $\mathrm{m}^{3}$ atau hanya sekitar $27 \%$ dari total $3.435 .600 \mathrm{~m}^{3}$ (dihitung dari 50\% volume petakan budidaya) minimum yang dibutuhkan, sehingga dengan tunggang pasut lebih kecil dari $1 \mathrm{~m}$ tentunya saluran-saluran tersebut bukan hanya tidak akan membantu memperbaiki kualitas kimia fisika air bahkan volume air tidak akan cukup secara kuantitas untuk mengisi petakan-petakan tambak hingga kedalaman/ketinggian air optimal dalam petakan. Dengan kondisi demikian maka fungsi utama saluran dalam mengalirkan sesuai dengan kuantitas dan kualitas untuk kebutuhan optimal organisme yang dibudidayakan di tambak tidak akan tercapai kecuali dengan bantuan teknologi (pompa).

\section{Implikasi Terhadap Keberlanjutan Tambak Silvofishery di Lokasi Penelitian}

Dari hasil analisis karakteristik rekayasa tambak, diketahui bahwa salah satu faktor utama yang memengaruhi pengelolaan tambak dan menjadi ancaman bagi keberlanjutan silvofishery di lokasi penelitian adalah kondisi tidal flushing yang kurang efektif. Menurut Wibowo \& Handayani (2006), keberhasilan pengelolaan hutan mangrove sangat dipengaruhi oleh terjaganya tidal flushing untuk memediasi masuknya benih alam, input nutrien utama, mengangkut sampah, dan menjaga kelayakan kualitas air. Selain karena ketidaksesuaian rekayasa saluran pada tahap awal, terganggunya tidal flushing di daerah penelitian diduga kuat akibat kurangnya monitoring dan evaluasi pengelolaan dan pengembangan tanah tumbuh yang ada di sepanjang pantai. Pembangunan tambak baru di tanah tumbuh tersebut bukan hanya menyempitkan mulut saluran, bahkan di beberapa titik telah menutup atau mengalihkan aliran hanya ke petakan tertentu sehingga hanya tambak berdekatan dengan laut yang mendapatkan tidal flushing optimal. Petakan-petakan tambak tersebut juga dibangun dengan teknologi seadanya menggunakan tenaga manusia sehingga dasar tambak umumnya lebih tinggi dari muka laut rata-rata. Dengan demikian petakan-petakan tambak dekat garis pantai tersebut cenderung menyerupai tanggul yang menghambat bilasan pasut. Akibatnya petakan-petakan tambak yang letaknya cukup jauh dari garis pantai sulit mendapatkan kualitas air dengan salinitas yang layak untuk budidaya ataupun untuk masuk dan berkembangnya (benih) ikan/udang liar yang justru merupakan sumber pedapatan harian yang kadangkala melebihi hasil budidaya. Mangrove Avicenia, meskipun memiliki kadar toleransi terhadap salinitas yang tinggi akhirnya tidak dapat dipertahankan mengikuti kepadatan yang disepakati antara warga pembudidaya dan perum perhutani. Beberapa petakan tambak yang berbatasan dengan sawah tersebut saat ini juga sedang diupayakan untuk dialihfungsikan menjadi tambak intensif vaname, namun demikian telah berulangkali mengalami kegagalan yang diduga akibat menurunnya kualitas air utamanya pada saat musim hujan.

Aspek rekayasa tambak silvofishery di lokasi penelitian yang juga harus mendapatkan perhatian khusus adalah kondisi rasio hutan (mangrove) dan tambak (kolam). Menurut Wibowo \& Handayani (2006), pengelola tambak dan Dinas Kehutanan di Kecamatan Blanakan Kabupaten Subang, menyepakati rasio mangrove tambak yang harus dipenuhi oleh pengelolaan tambak $80 \%$ mangrove dan $20 \%$ tambak. Jika perbandingan mangrove dan tambak $50 \%-80 \%$ : $20 \%-50 \%$ pengelola tambak diberi peringatan dan jika perbandingan antara mangrove dan tambak mencapai $50 \%$ : 50\% ijin pengelolaan dicabut. Hasil observasi lapang dan analisis citra worldview-2 menunjukkan kondisi luasan mangrove rata-rata dalam tambak saat ini justru $<50 \%$, namun tetap dibiarkan beroperasi. Selain rasio tambak mangrove, pemilihan jenis mangrove memang sejak awal sudah menjadi bagian dari konflik, perum perhutani lebih menyukai jenis Rhizophora karena tingkat toleransi yang tinggi dari banjir, produksi kayu, dan kemudahan benih untuk tumbuh, namun pengelola tambak lebih memilih Avicennia karena daunnya yang tidak toksik bahkan dapat menyuburkan lahan (Primavera, 2000). Petani yang bekerja di lahan pemerintah (perhutani) akan kesulitan mendapatkan bantuan kredit untuk perbaikan pengelolaan sehingga cenderung tidak memperhatikan rasio mangrove (Burbridge \& Koesbiono, 1984; Sukardjo, 1989). Kondisi demikian bukan hanya akan menurunkan produktivitas lahan akan tetapi lebih jauh akan mengganggu fungsi ekologis atau konservasi dan memicu timbulnya konflik antara perum perhutani sebagai pemegang kuasa kepemilikan lahan dan masyarakat pengelolaan tambak.

Jika tidak ada langkah strategis yang dilakukan oleh pemerintah untuk menyelesaikan masalah tersebut, maka tujuan utama dengan adanya sistem silvofishery yakni meredakan konflik sekaligus meningkatkan produktivitas lahan akan sulit tercapai. Langkah pertama yang harus diupayakan adalah pemerintah harus mendata ulang kepemilikan lahan termasuk proses perijinannya untuk memudahkan kegiatan monitoring dan evaluasi. Monitoring dan evaluasi kegiatan harus meliputi aspek teknis, sosial, ekonomi, dan ekologis. Aspek teknis paling mendesak di lokasi penelitian adalah sesegera mungkin dilakukan revitalisasi saluran dan evaluasi desain tambak yang memungkinkan efektifnya tidal flushing. Selanjutnya menurut Sutirda (2000), perlu penerapan program perijinan (licensing program) pada segala macam aktivitas komersial dalam wilayah mangrove sebagai pengontrol jangka pendek yang menyeimbangkan 
kepentingan lingkungan, pengembangan, dan sosial. Sebagai bagian dari licensing program tersebut pemerintah harus secara tegas memberikan sanksi bagi pengelola tambak yang mengingkari kewajibannya.

\section{KESIMPULAN}

Dari hasil penelitian dapat disimpulkan bahwa karakteristik rekayasa saluran tambak eksisting khususnya saluran laut merupakan aspek rekayasa tambak yang paling utama berpengaruh terhadap keberlangsungan tambak silvofishery di lokasi penelitian. Ketersediaan air yang sesuai secara kuantitas dan kualitas untuk petakan tambak silvofishery tidak terpenuhi secara optimal sehubungan dengan ketidaksesuaian lebar dan kedalaman saluran dengan kondisi tunggang pasut lokal $(<1 \mathrm{~m})$. Fungsi saluran tambak yang dari awal kurang optimal menjadi lebih tidak efektif dengan sedimentasi yang tinggi di mulut dan sepanjang dinding saluran laut. Penurunan efektivitas fungsi saluran dan variasi spasial elevasi dasar tambak akibat sedimentasi dan pengelolaan tanah tumbuh di sepanjang pantai juga menyebabkan variasi nilai salinitas air tambak hingga pada nilai yang melewati nilai yang layak untuk kegiatan budidaya. Selanjutnya penelitian ini juga menemukan ketinggian pematang primer dan sekunder eksisting umumnya lebih rendah dibandingkan ketinggian pematang ideal sehingga sewaktu-waktu dapat menjadi masalah yang serius jika terjadi kondisi pasang atau banjir yang ekstrem. Status kepemilikan lahan tambak yang utamanya dikuasai oleh perum perhutani juga menjadi faktor pembatas untuk pengembangan wilayah dan produksi tambak. Jika ketidaksesuaian rekayasa tambak termasuk faktor pembatas lingkungan yang diidentifikasi tersebut tidak ditangani dengan baik tentunya akan mengancam keberlanjutan kegiatan budidaya berbasis silvofishery di lokasi penelitian.

\section{DAFTAR ACUAN}

Abidin, H.Z., \& Sutrisno. (2011). Peta geologi lembar Pamanukan, Jawa. In Peta bersistem Indonesia. (Eds.). Simandjuntak, T.O., \& Gafoer, S. Pusat Survei Geologi, Badan Geologi, Kementerian Energi dan Sumberdaya Mineral. Jakarta, $1 \mathrm{hlm}$.

Agus, F., Yusrial, \& Sutono, S. (2006). Penetapan tekstur tanah. Dalam Kurnia, U., Agus, F., Adimihardja, A., \& Dariah, A. (Eds.), Sifat fisik tanah dan metode analisisnya. Balai Besar Penelitian dan Pengembangan Sumberdaya Lahan Pertanian, Badan Penelitian dan Pengembangan Pertanian. Jakarta, $282 \mathrm{hlm}$.

Alcantara, L.O. (1982). Variations of fishpond layouts for different types of brackishwater fishpond management. Report of consultation/Seminar on coastal fishpond engineering (4-12 Agustus 1982, Surabaya, Indonesia. Food and Agriculture organization (FAO) \& South China Sea Fisheries Development Coordinating Programme (SCSFDCP). Manila, Philippines. p. SCS/82/CFP/CP-88 (213).

Antara. (2012). "Program revitalisasi tambak udang dan bandeng dimulai." Diakses, 3 Maret, 2014, dari http:/www.antarasumsel.com/print/268385/ program-revitalisasi-tambak-udang-dan-bandengdimulai.

Antara-Kalsel. (2012). "Seribu hektar tambak siap direvitalisasi”. Diakses, 2 Januari 2014, dari http:/ /kalsel.antaranews.com/rilis-pers/345249/seribuhektar-tambak-siap-direvitalisasi.

Bappeda-Kabupaten Subang. (2010). Laporan akhir kajian pengembangan minapolitan di pantura Kabupaten Subang. Pemerintah Kabupaten Subang, Badan Perencanaan Pembangunan Daerah (Bappeda) bekerjasama dengan PT. Pilar Artha Nugraha. Subang, 299 hlm.

Bengen, D.G. (2002). Pedoman teknis pengenalan dan pengelolaan ekosistem mangrove. Pusat Kajian Sumberdaya Pesisir dan Lautan. Institut Pertanian Bogor (PKSPL-IPB). Bogor, $58 \mathrm{hlm}$.

BMKG-Darmaga. (2014). Buletin analisis hujan bulan Desember 2013 dan perkiraan hujan bulan Februari, Maret, dan April 2014 di wilayah Jawa Barat. Badan Meteorologi Klimatologi dan Geofisika, Stasiun Klimatologi Klas I Darmaga Bogor. Bogor, $53 \mathrm{hlm}$.

Bose, A.N., Ghosh, S.N., Yang, C.T., \& Mitra, A. (1991). Coastal Aquaculture Engineering. Edward Arnold. New York, 360 pp.

Boyd, C.E. (1995). Bottom soils, sediment, and pond aquaculture. Chapman and Hall. New York, 348 pp.

Boyd, C.E., \& Wood, C.W. (2002). Aquaculture pond bottom soil quality management. Pond/dynamics/ Aquaculture Collaborative Research Support Program Oregon State University. Oregon, $41 \mathrm{pp}$.

Bray, W.A., Lawrence, L.A., \& Leung-Trujillo, J.R. (1994). The effect of salinity on growth and survival of Penaeus vannamei, with observations on the interaction of ihhn virus and salinity. Aquaculture, 122, 133-146.

Burbridge, P.R., \& Koesbiono. (1984). Management of mangrove exploitation in Indonesia. In Soepadmo, E., Rao, A.N., \& Macintosh, D.J. (Eds.). Proceedings Asian Symposium on Mangrove Environment: Research and Management. Kuala Lumpur, 25-29 Augst 1980. University of Malaya and UNESCO, p. 740-760.

Burrough, P.A., \& McDonnell, R.A. (1998). Principles of geographical information systems. Oxford University Press Inc. New York, 333 pp.

Cruz, C.L. dela. (1983). Fishpond engineering: a technical manual for small- and medium-scale coastal fish farms in SE Asia. South China Sea Programme, SCS-manual, No. 5, 180 pp. 
Denila, L. (1976). Layout, design, construction and levelling of fishponds. Readings on pond construction and management. SEAFDEC Aquaculture Department. Tigbauan Iloilo. Philippines, p. 73-83.

DigitalGlobe. (2014). Digital globe, www.dgitalglobe.com. Diakses, tanggal 12 Februari tahun 2014.

HyDIS-G-WADI. (2014). UNESCO G-WADI Global RealTime Precipitation, the G-WADI-GeoServer. http:/ /hydis.eng.uci.edu/gwadi/.

Ilyas, S., Cholik, F., Poernomo, A., Ismail, W., Arifudin, R., Daulay, T., Ismail, A., Koesoemadinata, S., Rabegnatar, I N.S., Soepriyadi, H., Suharto, H. H. Azwar, Z.I., \& Ekowardoyo, S. (1987). Petunjuk teknis bagi pengoperasian unit usaha pembesaran udang windu. Pusat Penelitian dan Pengembangan Perikanan. Jakarta, 99 hlm.

Johnston, D., Trong, N.V., Tien, D.V., \& Xuan, T.T. (2000). Shrimp yields and harvest characteristics of mixed shrimp-mangrove forestry farms in Ca Mau Province: factors affecting production. Aquaculture, 188, 263-284.

Karthik, M., Suri, J., Saharan, N., \& Biradar, R.S. (2005). Brackish water aquaculture site selection in Palghar Taluk, Thane distcrict of Maharashtra, India, using techniques of remote sensing and geographical information system. Aquaculture Engineering, 32, 285-302.

KKP. (2011). Kelautan dan perikanan dalam angka 2011. Kementerian Kelautan dan Perikanan. Jakarta, 99 hlm.

KUD-MKBS. (2013). Nominatif pemilik tambak. KUD Mina Karya Bukti Sejati Desa Jayamukti, Subang. $12 \mathrm{hlm}$.

Lekang, O. (2007). Aquaculture engineering. First edition. Blackwell Publishing. Oxford-UK. 340 pp.

Masselink, G., \& Hughes, M.G. (2003). Introduction to coastal processes and geomorphology. Arnold. New York, 354 pp.

Menavesta, P. (1982). Environmental considerations for the development of coastal fishfarms in the Indo-Pacific Region. Report of consultation/Seminar on coastal fishpond engineering (4-12 Agustus 1982, Surabaya, Indonesia. Manila, Philippines: Food and Agriculture organization (FAO) \& South China Sea Fisheries Development Coordinating Programme (SCSFDCP). p. SCS/82/CFP/CP-24 (213).

Menon, R.G. (1988). Soil and water analysis: a laboratory manual for the analysis of soil and water. Proyek Survey O.K.T. Sumatera Selatan. Palembang, 191 p.

Mustafa, A. (2007). Improving acid sulfate soils for brackishwater aquaculture ponds in South Sulawesi,
Indonesia. PhD Thesis. The University of New South Wales. Australia, 408 pp.

Poernomo, A. (1988). Pembuatan tambak udang di Indonesia. Departmen Pertanian, Badan Penelitian dan Pengembangan Pertanian, Balai Penelitian Perikanan Budidaya Pantai. Maros, 30 hlm.

Poernomo, A. (1992). Pemilihan lokasi tambak udang berwawasan lingkungan. Badan Penelitian dan Pengembangan Pertanian, Pusat Penelitian dan Pengembangan Perikanan bekerja sama dengan USAID/FRDP. Jakarta, $40 \mathrm{hlm}$.

Primavera, J.H. (2000). Integrated mangrove-aquaculture systems in Asia. Paper presented at the Integrated Coastal Zone Management. Autumn edition, p. 121-130.

Purwiyanto, A.I.S., \& Agustriani, F. (2014). Effect of silvofishery on ponds nutrient levels. Ilmu Kelautan, 19(2), 81-87.

Purworaharjo, U.U. (1986). Ilmu ukur tanah seri b: pengukuran tinggi. Jurusan Teknik Geodesi Fakultas Teknik Sipil dan Perencanaan Institut Teknologi Bandung. Bandung, $82 \mathrm{hlm}$.

Sambu, H.A. (2013). Otimasi pengelolaan silvofishery di kawasan pesisir Kabupaten Sinjai. Disertasi. Sekolah Pascasarjana, Institut Pertanian Bogor. Bogor, $173 \mathrm{hlm}$.

Sammut, J. (2002). Land capability assessment and classification for sustainable pond-based aquaculture systems (ACIAR FIS/2002/076): Australian Centre for International Agricultural Research (ACIAR) \& University of New South Wales (UNSW). http://aciar.gov.au/project/FIS/2002/076.

Sukardjo, S. (1989). Tumpang sari pond as a multiple use concept to save the mangrove. In: Soerianegara, I., Zamora, P.M., Kartawinata, K., Umaly, R.C., Tjitrosomo, S., Sitompul, D.M., \& Syafii, URD. 1989. Proceedings of the symposium on mangrove management: its ecological and economic considerations. BIOTROP Special Publication No. 37, SEAMEO-BIOTROP, Southeast Asian Center for Tropical Biology, Bogor. Indonesia, p. 115-128.

Sutirda, M.B. (2000). Silvofisheries in Indonesia. SEAFDEC Asian Aquaculture, XXII, 20-28.

Swingle, H.S. (1968). Standardization of chemical analysis for waters and pond muds. FAO Fisheries Report, 44(4), 397-406.

Triyanto, Wijaya, N.I., Widiyanto, T., Yuniarti, I., Setiawan, F., \& Lestari, F.S. (2012). Pengembangan silvofishery kepiting bakau (Scylla serrata) dalam pemanfaatan kawasan mangrove di Kabupaten Berau, Kalimantan Timur. Prosiding Seminar Nasional Limnologi VI Tahun 2012, hlm. 739-751.

Wibowo, K., \& Handayani, T. (2006). Pelestarian hutan mangrove melalui pendekatan mina hutan (silvofishery). J. Tek. Ling., 7(3), 227-233. 